\title{
Faktor yang Mempengaruhi Rencana Pemilihan Tempat Persalinan pada Pasien Peserta JKN di Poliklinik Kandungan dan Kebidanan Rumah Sakit Pertamina Bintang Amin Bandar Lampung Tahun 2019
}

\section{Factors Affecting the Planned Place of Delivery for JKN Participant Patients at the Gynecology and Obstetrics Polyclinic of Pertamina Bintang Amin Hospital Bandar Lampung in 2019}

\author{
Arif Rahman Hakim ${ }^{1}$, Lolita Sary ${ }^{2}$, Nova Muhani \\ ${ }^{1}$ Fakultas Kesehatan Masyarakat Universitas Muhammadiyah, Lampung, \\ Indonesia \\ *Korespondensi penulis: pratiwiarh@gmail.com
}

Penyerahan: 08-08-2019, Perbaikan: 18-03-2020, Diterima: 26-03-2020

\begin{abstract}
Health services during pregnancy, childbirth, and puerperal are very important for the survival of the mother and baby, including in efforts to reduce maternal and newborn mortality. The high number of ANC visits at Pertamina Bintang Amin Hospital was not followed by high utilization of obstetric inpatients. The purpose of this study was to determine the factors that influence labor plan in JKN participants in obstetric and midwifery clinic.This research was a quantitative study with a cross sectional study approach. Total population of 417 people, with a sample of 101 people and taken by purposive sampling. The research data were obtained from the results of questionnaires for labor plan and the characteristics of respondents (employment, education, access to health services, economic status, and medical diagnosis). Bivariate analysis was performed using the Chi-Square test. Multivariate analysis was performed with logistic binary regression tests. The results showed that the most frequent frequency distribution of respondents in the FKTP delivery place selection plan category (75 people, $74.3 \%$ ), IRT work (59 people, 58.4\%), tertiary education (52 people, 51.5\%) , good economic status (76 people, 75.2\%), access to close health services (60 people, 59.4\%), and diagnosis of low-risk medical personnel (75 people, $74.3 \%$ ). The most dominant factor in influencing planned delivery of labor was diagnosis by medical personnel $(p<0,001)$.
\end{abstract}

Keywords: Plan, Labor, JKN, Hospital, Antenatal care.

\section{ABSTRAK}

Pelayanan kesehatan selama masa kehamilan, persalinan, dan nifas sangat penting bagi keberlangsungan hidup ibu dan bayi, termasuk dalam upaya menurunkan angka kematian ibu dan bayi baru lahir. Tingginya angka kunjungan ANC di Rumah Sakit Pertamina Bintang Amin tidak diikuti dengan tingginya pemanfaatan rawat inap kebidanan. Tujuan penelitian ini adalah mengetahui faktor-faktor yang mempengaruhi rencana pemilihan tempat persalinan pada pasien peserta JKN di poliklinik kandungan dan kebidanan. Penelitian ini merupakan penelitian kuantitatif dengan pendekatan studi cross sectional. Jumlah populasi 417 orang, dengan jumlah sampel 101 orang dan diambil dengan purposive sampling. Data penelitian diperoleh dari hasil kuesioner rencana pemilihan tempat persalinan dan karakteristik responden (pekerjaan, pendidikan, akses pelayanan kesehatan, status ekonomi, dan diagnosis tenaga medis). Analisis bivariat dilakukan dengan uji Chi-Square. Analisis multivariat dilakukan dengan uji regresi binari logistik. Hasil penelitian menunjukkan bahwa distribusi frekuensi

Jurnal Dunia Kesmas, Vol. 9 No. 2, April 2020, hal. 223 - 234 
responden paling banyak pada kategori rencana pemilihan tempat persalinan FKTP (75 orang, $74,3 \%)$, pekerjaan IRT (59 orang, 58,4\%), pendidikan perguruan tinggi (52 orang, $51,5 \%$ ), status ekonomi baik ( 76 orang, $75,2 \%$ ), akses pelayanan kesehatan dekat (60 orang, 59,4\%), dan diagnosis tenaga medis risiko rendah ( 75 orang, $74,3 \%$ ). Faktor yang paling dominan dalam mempengaruhi rencana pemilihan tempat persalinan adalah diagnosis tenaga medis $(p<0.001)$.

Kata kunci: Rencana, Persalinan, JKN, Rumah Sakit, ANC.

\section{PENDAHULUAN}

Pelayanan kesehatan selama masa kehamilan, persalinan, dan nifas sangat penting bagi keberlangsungan hidup ibu dan bayi, termasuk dalam upaya menurunkan angka kematian ibu dan bayi baru lahir. Pelayanan kesehatan ibu menjadi prioritas utama pembangunan kesehatan nasional maupun global. Pemerintah Republik Indonesia telah menargetkan peningkatan cakupan pelayanan kesehatan ibu sebagaimana tercantum dalam Rencana Pembangunan Jangka Menengah Nasional (RPJMN) 20152019 dan Rencana Strategis (Renstra) Kementerian Kesehatan 2015-2019 (Kementerian Kesehatan RI, 2015). Kematian ibu merupakan salah satu masalah kesehatan yang masih berusaha untuk diselesaikan di Indonesia. Berdasarkan data yang dihimpun oleh Badan Pusat Statistik, angka kematian ibu (yang berkaitan dengan kehamilan, persalinan, dan nifas) pada tahun 2015 sebesar 305 per 100.000 kelahiran hidup. Angka ini masih cukup tinggi apalagi jika dibandingkan dengan negara-negara tetangga di Asia Tenggara. Angka ini juga masih jauh dari target Sustainable Development Goals (SDGs) yang ingin dicapai pada tahun 2030 sebesar 70/100.000 kelahiran hidup, walaupun jumlah persalinan yang ditolong oleh tenaga kesehatan mengalami peningkatan (Badan Pusat Statistik Indonesia, 2015; United Nations, 2015).
Peningkatan jumlah persalinan yang ditolong oleh tenaga kesehatan dipengaruhi beberapa faktor, seperti ibu hamil dengan gaya hidup tinggi, pendidikan tinggi, tingkat ekonomi yang mumpuni, dukungan suami, dan lingkungan akan sangat mempengaruhi tempat bersalin terutama di fasilitas kesehatan yang lebih tinggi tingkatannya seperti rumah sakit. Ibu hamil yang sudah mengalami tanda-tanda persalinan diberikan kebebasan untuk meminta pertolongan persalinan ke tenaga kesehatan yang menyediakan pelayanan persalinan, yaitu puskesmas pembantu, pondok bersalin desa/pos kesehatan desa, puskesmas, rumah sakit bahkan beberapa orang seperti lebih memilih dukun beranak dalam membantu persalinannya. Namun ibu hamil yang tinggal di daerah urban lebih memilih persalinan di fasilitas kesehatan modern yang lebih baik seperti di rumah sakit (Baba et al., 2016; Badan Kependudukan dan Keluarga Berencana Nasional et al., 2017).

Berdasarkan data profil kesehatan Indonesia tahun 2018, cakupan pertolongan persalinan oleh tenaga kesehatan dengan kompetensi kebidanan sejak tahun 2013 $(88,64 \%)$ sampai tahun 2018 cenderung mengalami peningkatan, yaitu mencapai 93,1\%. Namun, peningkatan persalinan oleh tenaga kesehatan di Indonesia belum diimbangi dengan peningkatan jumlah persalinan di sarana 
pelayanan kesehatan. Pada tahun 2018, persalinan ibu dari kelahiran lima tahun terakhir menunjukkan bahwa $80 \%$ melahirkan di fasilitas kesehatan seperti rumah sakit (pemerintah dan swasta), rumah bersalin, Puskesmas, Puskesmas pembantu, praktek dokter atau praktek bidan. Terdapat 16\% melahirkan di rumah/lainnya dan hanya 4 persen yang melahirkan di pondok bersalin desa/pos kesehatan desa (Kementerian Kesehatan RI, 2018).

Cakupan pemilihan tempat persalinan di Provinsi Lampung yang berlangsung di rumah/lainnya cukup tinggi, yaitu mencapai 30\% sedangkan $70 \%$ melahirkan di fasilitas kesehatan (rumah sakit, puskesmas, polindes/ poskesdes) (Kementerian Kesehatan RI, 2013). Provinsi Lampung memiliki 63 rumah sakit, yang terdiri dari 50 rumah sakit swasta dan 13 rumah sakit negeri yang bertipe $B$ dan $C$. Rumah Sakit yang bertipe B dan $C$ adalah rumah sakit rujukan dari Puskesmas yang diperbolehkan melakukan pertolongan persalinan dengan menggunakan pembiayaan JKN atau mandiri. Salah satu rumah sakit swasta bertipe $C$ adalah Rumah Sakit Pertamina Bintang Amin yang berada di kota Bandar Lampung.

Berdasarkan data di Rumah Sakit Pertamina Bintang Amin, jumlah kunjungan pasien JKN ke Poliklinik Kandungan dan Kebidanan pada tahun 2015 sebanyak 541 pasien, tahun 2016 sebanyak 647 pasien dan pada tahun 2017 sebanyak 471 pasien. Namun pada kenyataannya, tingginya angka kunjungan ANC tidak diikuti dengan tingginya pemanfaatan rawat inap kebidanan di rumah sakit. Pemanfaatan rawat inap kebidanan JKN di Rumah Sakit Pertamina Bintang Amin pada tahun 2015 sebanyak 700 pasien, pada tahun 2016 sebanyak 561 pasien dan pada tahun 2017 sebanyak 359 pasien. Data pasien JKN yang melakukan ANC di Rumah Sakit Pertamina Bintang Amin pada tahun 2018 menunjukkan bahwa diagnosis rujukan paling banyak adalah kehamilan dengan letak lintang, diikuti dengan ketuban pecah dini. Rujukan ini diberikan dari berbagai Fasilitas Kesehatan Tingkat Pratama (FKTP), yaitu Puskesmas, Klinik Pratama, dan Bidan Praktik Mandiri di Kota Bandar Lampung.

Berdasarkan latar belakang dan uraian di atas, maka penulis tertarik melakukan pengkajian dan penelitian mengenai: "Faktor-Faktor yang Mempengaruhi Rencana Pemilihan Tempat Persalinan Pada Pasien Peserta JKN di Poliklinik Kandungan dan Kebidanan Rumah Sakit Pertamina Bintang Amin Bandar Lampung Tahun 2019 "

\section{METODE}

Jenis penelitian ini adalah analitik observasional dengan pendekatan cross sectional (Notoatmodjo, 2012a). Penelitian ini dilakukan di Rumah Sakit Pertamina Bintang Amin Bandar Lampung. Lokasi penelitian dipilih berdasarkan pertimbangan bahwa merupakan rumah sakit tipe $C$ tempat pelayanan persalinan, dan bekerjasama dengan BPJS selaku pelaksana JKN dan tingginya angka kunjungan ANC di poliklinik kandungan dan kebidanan tidak diikuti oleh tingginya angka pemanfaatan pelayanan persalinan. Penelitian ini dilaksanakan pada bulan Maret 2018 - Oktober 2019. Populasi pada penelitian ini adalah seluruh pasien peserta JKN di poliklinik kandungan dan kebidanan Rumah Sakit Pertamina Bintang Amin yang menerima layanan ANC. Selama tahun 2017, jumlah pasien JKN di poliklinik kandungan dan 
kebidanan Rumah Sakit Pertamina Bintang Amin yang menerima layanan ANC adalah 417 pasien, dengan rata-rata 35 pasien setiap bulannya. Teknik pengambilan sampel menggunakan purposive sampling. Besar sampel dihitung menggunakan proporsi berdasarkan rumus Lameshow.

Peneliti mengambil sampel dengan jumlah paling besar, sehingga jumlah sampel yang dibutuhkan minimal adalah 101 orang. Teknik pengampilan sampel yang digunakan dalam penelitian ini adalah nonprobability sampling, yaitu purposive sampling. Kriteria inklusi: Pasien poliklinik kandungan dan kebidanan yang datang untuk melakukan pemeriksaan antenatal care; merupakan pasien peserta program Jaminan Kesehatan Nasional (JKN); bersedia menjadi responden penelitian. Kriteria Ekslusi: dalam kondisi gawat-darurat yang membutuhkan penanganan segera; pasien merupakan pegawai di Rumah Sakit Pertamina Bintang Amin dan pasien berusia di bawah 17 tahun. Pengambilan data yang dilakukan pada penelitian ini menggunakan kuesioner. Pengisian kuesioner dilakukan dengan mengedarkan daftar pertanyaan tertulis kepada responden untuk mendapatkan tanggapan, informasi, dan jawaban terkait masalah yang sedang diteliti. Kuesioner yang diberikan telah melewati uji validitas dan reliabilitas sebelumnya. Dalam penelitian ini variabel-variabel uang dibutuhkan, yaitu variabel bebas adalah pekerjaan, pendidikan, status ekonomi, akses pelayanan kesehatan, dan diagnosis tenaga medis, dan variabel terikat adalah rencana pemilihan tempat persalinan.

\section{HASIL}

\section{Tabel 1. Distribusi Frekuensi Karakteristik Responden}

\begin{tabular}{lll}
\hline Variabel & Jumlah & Persentase \\
\hline Rencana Pemilihan Tempat Persalinan & & \\
FKTP & 76 & 75,2 \\
FKTL & 25 & 24,8 \\
Pekerjaan & & \\
IRT & 59 & 58,4 \\
PNS & 13 & 12,9 \\
Karyawan Swasta & 21 & 20,8 \\
Wirausaha & 8 & 7,9 \\
& & \\
Pendidikan & & \\
Perguruan Tinggi & 52 & 51,5 \\
SMA & 38 & 37,6 \\
SMP & 8 & 7,9 \\
SD & 3 & 3,0 \\
Status Ekonomi & & \\
Baik & & \\
Kurang Baik (< Rp. 2.445.141,15,-/bulan) & 25 & 76,2 \\
Akses pelayanan kesehatan & & 24,8 \\
Dekat (< 2 km) & & \\
Jauh (>2 km) & 60 & 59,4 \\
Diagnosis tenaga medis & 41 & 40,6 \\
Risiko Rendah & & \\
Risiko Tinggi & 75 & 74,3 \\
\hline
\end{tabular}


Berdasarkan tabel 1 diketahui bahwa distribusi frekuensi rencana pemilihan tempat persalinan lebih banyak pada kategori FKTP (Puskesmas/Klinik Pratama, Dokter Praktek Mandiri, Bidan Praktek Mandiri), pekerjaan responden terbanyak adalah IRT, pendidikan tertinggi responden paling banyak adalah perguruan tinggi dengan status ekonomi responden pada kategori baik cukup banyak. Diketahui bahwa rata-rata akses pelayanan kesehatan responden dekat dan diagnosis dokter ada pada level risiko rendah sebanyak 75 orang $(74,3 \%)$.

Tabel 2. Hubungan Pekerjaan, Pendidikan, dan Rencana Pemilihan Tempat Persalinan

\begin{tabular}{|c|c|c|c|c|c|c|c|}
\hline \multirow{3}{*}{ Variabel } & \multicolumn{4}{|c|}{$\begin{array}{c}\text { Rencana Pemilihan Tempat } \\
\text { Persalinan }\end{array}$} & \multicolumn{2}{|c|}{ Total } & \multirow{3}{*}{$\begin{array}{l}\text { P-value } \\
\text { OR (95\%CI) }\end{array}$} \\
\hline & \multicolumn{2}{|c|}{ FKTP } & \multicolumn{2}{|c|}{ FKTL } & \multirow[b]{2}{*}{$\mathbf{N}$} & \multirow[b]{2}{*}{$\%$} & \\
\hline & n & $\%$ & n & $\%$ & & & \\
\hline \multicolumn{8}{|l|}{ Pekerjaan } \\
\hline IRT & 47 & 79,7 & 12 & 20,3 & 59 & 100 & 0,940 \\
\hline PNS & 3 & 23,1 & 10 & 76,9 & 13 & 100 & \\
\hline Karyawan Swasta & 19 & 90,5 & 2 & 9,5 & 21 & 100 & \\
\hline Wirausaha & 7 & 87,5 & 1 & 12,5 & 8 & 100 & \\
\hline \multicolumn{8}{|l|}{ Pendidikan } \\
\hline PT & 36 & 69,2 & 16 & 30,8 & 52 & 100 & 0,247 \\
\hline SMA & 32 & 84,2 & 6 & 15,8 & 38 & 100 & \\
\hline SMP & 8 & 72,7 & 3 & 27,3 & 11 & 100 & \\
\hline Status Ekonomi & & & & & & & 0,025 \\
\hline Baik & 53 & 69,7 & 23 & 30,3 & 76 & 100 & 0,2 \\
\hline Kurang Baik & 23 & 92,0 & 2 & 8,0 & 25 & 100 & $(0,04-0,9)$ \\
\hline \multicolumn{8}{|c|}{ Akses Pelayanan Kesehatan } \\
\hline Dekat & 48 & 80,0 & 12 & 20,0 & 60 & 100 & 0,181 \\
\hline Jauh & 28 & 68,3 & 13 & 31,7 & 41 & 100 & \\
\hline Diagnosis Tenaga Medis & & & & & & & $<0,001$ \\
\hline Risiko Rendah & 72 & 96,0 & 3 & 4,0 & 75 & 100 & 132 \\
\hline Risiko Tinggi & 4 & 15,4 & 22 & 84,6 & 26 & 100 & $(27,4-635,2)$ \\
\hline
\end{tabular}

Hasil analisis hubungan pekerjaan responden dengan rencana pemilihan tempat persalinan diperoleh bahwa di antara 59 responden yang bekerja sebagai IRT, terdapat 47 orang $(79,7 \%)$ berencana melakukan persalinan di FKTP dan 12 orang (20,3\%) berencana melakukan persalinan di FKTL. Di antara 13 responden yang bekerja sebagai PNS, terdapat 3 orang $(23,1 \%)$ berencana melakukan persalinan di FKTP, dan 10 orang $(76,9 \%)$ berencana melakukan persalinan di FKTL. Di antara 21 responden yang bekerja sebagai karyawan swasta, terdapat 19 orang $(90,5 \%)$ berencana melakukan persalinan di FKTP, dan 2 orang $(9,5 \%)$ berencana melakukan persalinan di FKTL.

Di antara 8 responden yang bekerja sebagai wirausaha, terdapat 7 orang $(87,5 \%)$ berencana melakukan persalinan di FKTP, dan 1 orang $(12,5 \%)$ berencana melakukan persalinan di FKTL. Hasil uji statistik diperoleh nilai $p=0,940 \quad(>0,05)$, maka diambil kesimpulan bahwa tidak ada hubungan pekerjaan 
dengan rencana pemilihan tempat persalinan.

Hasil analisis hubungan pendidikan responden dengan rencana pemilihan tempat persalinan diperoleh bahwa di antara 52 responden yang memiliki pendidikan terakhir pada kategori perguruan tinggi, terdapat 36 orang $(69,2 \%)$ berencana melakukan persalinan di FKTP, dan 16 orang $(30,8 \%)$ berencana melakukan persalinan di FKTL. Sementara di antara 38 responden yang memiliki pendidikan terakhir SMA, terdapat 32 orang $(84,2 \%)$ berencana melakukan persalinan di FKTP, dan 6 orang $(15,8 \%)$ berencana melakukan persalinan di FKTL. Di antara 11 responden yang memiliki pendidikan terakhir SMP, terdapat 8 orang $(72,7 \%)$ berencana melakukan persalinan di FKTP, dan 3 orang $(27,3 \%)$ berencana melakukan persalinan di FKTL. Hasil uji statistik diperoleh nilai $p=0,247 \quad(>0,05)$, maka diambil kesimpulan bahwa tidak ada hubungan pendidikan dengan rencana pemilihan tempat persalinan.

Hasil analisis hubungan status ekonomi responden dengan rencana pemilihan tempat persalinan diperoleh bahwa di antara 76 responden dengan status ekonomi baik, terdapat 53 orang $(69,7 \%)$ berencana melakukan persalinan di FKTP, dan 23 orang $(30,3 \%)$ berencana melakukan persalinan di FKTL. Sementara di antara 25 responden dengan status ekonomi kurang baik, terdapat 23 orang $(92,0 \%)$ berencana melakukan persalinan di FKTP, dan 2 orang $(8,0 \%)$ berencana melakukan persalinan di FKTL. Hasil uji statistik diperoleh nilai $p=0,025 \quad(<0,05)$, maka diambil kesimpulan bahwa ada hubungan status ekonomi dengan rencana pemilihan tempat persalinan. Dari hasil analisis diperoleh pula nilai $\mathrm{OR}=0,2$.

Hasil analisis hubungan akses pelayanan kesehatan dengan rencana pemilihan tempat persalinan diperoleh bahwa di antara 60 responden dengan akses pelayanan kesehatan dekat, terdapat 48 orang $(80,0 \%)$ berencana melakukan persalinan di FKTP, dan 12 orang $(20,0 \%)$ berencana melakukan persalinan di FKTL. Sementara di antara 41 responden dengan akses pelayanan kesehatan jauh, terdapat 28 orang $(68,3 \%)$ berencana melakukan persalinan di FKTP, dan 13 orang $(31,7 \%)$ berencana melakukan persalinan di FKTL. Hasil uji statistik diperoleh nilai $p=0,181$ $(>0,05)$, maka diambil kesimpulan bahwa tidak ada hubungan akses pelayanan kesehatan dengan rencana pemilihan tempat persalinan.

Hasil analisis hubungan diagnosis tenaga medis dengan rencana pemilihan tempat persalinan diperoleh bahwa di antara 75 responden yang memiliki risiko persalinan rendah, terdapat 72 orang $(96,0 \%)$ berencana melakukan persalinan di FKTP, dan 3 orang $(4,0 \%)$ berencana melakukan persalinan di FKTL. Sementara di antara 26 responden yang memiliki risiko persalinan tinggi, terdapat 4 orang $(15,4 \%)$ berencana melakukan persalinan di FKTP, dan 22 orang $(84,6 \%)$ berencana melakukan persalinan di FKTL. Hasil uji statistik diperoleh nilai $p=0,000$ $(<0,05)$, maka diambil kesimpulan bahwa ada hubungan antara diagnosis tenaga medis dengan rencana pemilihan tempat persalinan. Dari hasil analisis diperoleh pula nilai $\mathrm{OR}=132$, artinya responden yang memiliki diagnosis medis risiko rendah mempunyai peluang 132 kali lebih besar untuk 
merencanakan persalinan di FKTP dibandingkan dengan responden yang memiliki diagnosis tenaga medis risiko tinggi.

Tabel 3. Model Akhir Analisis Multivariat Regresi Binari Logistik antara Variabel Kandidat Rencana Pemilihan Tempat Persalinan

\begin{tabular}{lllll}
\hline Variabel & b & Nilai p & OR & CI 95\% \\
\hline Status Ekonomi & $-2,461$ & 0,035 & 0,085 & $0,009-0,846$ \\
\hline Diagnosis Tenaga Medis & 5,229 & 0,000 & 186,619 & $30,107-1156,7$ \\
\hline Constants & $-2,870$ & 0,000 & & \\
\hline
\end{tabular}

Dari tabel 3 dapat disimpulkan variabel yang paling dominan untuk terjadinya rencana pemilihan persalinan di FKTL adalah status ekonomi dan diagnosis tenaga medis. Dari model di atas dapat dijelaskan bahwa responden yang memiliki diagnosis tenaga medis risiko rendah mempunyai peluang merencanakan persalinannya di FKTP 186 kali lebih besar dibandingkan reponden yang memiliki diagnosis tenaga medis risiko tinggi setelah dikontrol variabel status ekonomi.

\section{PEMBAHASAN}

$\begin{array}{lll}\text { Hubungan } & \text { Pekerjaan } \\ \text { Rencana } & \text { Pemilihan } & \text { Tempat } \\ \text { Persalinan } & & \end{array}$

Hasil uji statistik diperoleh nilai $p=0,940 \quad(>0,05)$, maka diambil kesimpulan bahwa tidak ada hubungan antara pekerjaan dengan rencana pemilihan tempat persalinan. Hasil penelitian ini tidak sejalan dengan penelitian yang dilakukan oleh Rusdiyanti (2017) di Banjarmasin yang menunjukkan bahwa terdapat hubungan yang signifikan antara pekerjaan dengan pemilihan tempat persalinan $(p=0,004)$. Namun hasil penelitian ini sejalan dengan penelitian yang dilakukan oleh Fauzia (2014) di Jakarta yang menunjukkan bahwa tidak terdapat hubungan yang signifikan antara pekerjaan dengan pemilihan tempat persalinan $(p=0,209)$. Teori menyebutkan bahwa pekerjaan seseorang mempengaruhi pola konsumsinya. Pekerjaan merupakan salah satu faktor predisposing terhadap penggunaan pelayanan kesehatan. Dengan adanya kondisi jenis pekerjaan yang beragam, sudah barang tentu mempengaruhi kebutuhan dan keinginan yang sangat luas dan bervariasi pula. Dengan demikian maka jenispekerjaan mempunyai pengaruh yang sangat luas dan sangat beragam terhadap perilaku konsumen, khususnya dalam hal kesehatan. Menurut Engel, Blackwell, dan Miniard dalam Fauzia (2014), pekerjaan adalah indikator terbaik mengenai kelas sosial konsumen. pekerjaan yang dilakukan konsumen akan mempengaruhi gaya hidup dan basis penting untuk menyampaikan prestise, kehormatan dan respek. Seseorang yang memiliki pekerjaan memiliki wawasan yang lebih luas daripada ibu rumah tangga. Karena pergaulan yang lebih luas dimana pertukaran informasi serta interaksi dengan rekan atau teman sering dilakukan. Masyarakat dengan lingkungan kota tentu memiliki lingkungan sosial yang berbeda dengan masyarakat di pedesaan. Hasil penelitian ini dapat disebabkan karena peserta yang menjadi responden adalah peserta program JKN. Sebagai program pemerintah, JKN mampu menjangkau seluruh lapisan masyarakat, tanpa memandang status sosialnya, termasuk pekerjaan yang dimiliki. Dengan demikian, kesejangan pertukaran informasi yang dapat 
timbul karena pekerjaan dapat diminimalisir. Hal ini dapat dilihat dari hasil penelitian yang menunjukkan

bahwa dari seluruh segmen pekerjaan, sebagian besar responden $(>50 \%)$

merencanakan persalinannya di FKTP.

$\begin{array}{lll}\text { Hubungan } & \text { Pendidikan dengan } \\ \text { Rencana } & \text { Pemilihan } & \text { Tempat } \\ \text { Persalinan } & & \end{array}$

Hasil uji statistik diperoleh nilai $p=0,247 \quad(>0,05)$, maka diambil kesimpulan bahwa tidak ada hubungan antara pendidikan dengan rencana pemilihan tempat persalinan. Hasil ini berbeda dengan hasil penelitian yang dilakukan oleh Putri (2016) di Jambi menunjukkan bahwa terdapat hubungan yang signifikan antara tingkat pendidikan dengan pemilihan tempat persalinan $(p=0,022)$. Hasil penelitian ini sejalan dengan penelitian yang dilakukan oleh Lumi (2014) di Surakarta yang menunjukkan bahwa tidak terdapat hubungan yang signifikan antara pendidikan dengan rencana pemilihan tempat persalinan $(p=0,139)$. Hasil penelitian ini juga tidak sejalan dengan teori yang menyebutkan bahwa pendidikan diyakini dapat mempengaruhi permintaan pelayanan medis. Pendidikan yang lebih baik di dalam rumah tangga memungkinkan keluarga untuk mengenalai gejala awal penyakit, sehingga kesediaan untuk mencari pelayanan kesehatan juga lebih baik. Tingginya tingkat pendidikan juga dapat menyebabkan efisiensi dalam penggunaan pelayanan medis (Priyoto, 2019). Hasil penelitian ini dapat disebabkan karena peserta yang menjadi responden adalah peserta program JKN. Sebagai program pemerintah, JKN mampu menjangkau seluruh lapisan masyarakat, tanpa memandang status sosialnya, termasuk pekerjaan yang dimiliki. Dengan demikian, kesejangan pertukaran informasi yang dapat timbul karena pendidikan dapat diminimalisir. Salah satu fungsi FKTP yang dimaksimalkan dalam era JKN adalah fungsi promotif, sehingga informasi terkait dengan pemilihan tempat persalinan dapat tersampaikan kepada seluruh lapisan masyarakat. Hal ini dapat dilihat dari hasil penelitian yang menunjukkan bahwa dari seluruh strata pendidikan, sebagian besar responden (>50\%) merencanakan persalinannya di FKTP.

\section{Hubungan Status Ekonomi dengan Rencana Pemilihan Tempat Persalinan}

Hasil uji statistik diperoleh nilai $p=0,025 \quad(<0,05)$, maka diambil kesimpulan bahwa ada hubungan antara status ekonomi dengan rencana pemilihan tempat persalinan. Dari hasil analisis diperoleh pula nilai $\mathrm{OR}=0,2$, artinya responden yang memiliki status ekonomi baik mempunyai peluang 0,2 kali lebih besar untuk merencanakan persalinan di FKTL dibandingkan dengan responden yang memiliki status ekonomi kurang baik. Hasil penelitian ini sejalan dengan penelitian yang dilakukan oleh Wulandari et al. (2016) di Sulawesi Tenggara, yang menunjukkan bahwa terdapat hubungan yang signifikan antara status ekonomi dengan pemanfaatan pelayanan kesehatan $(p=0,028)$. Hasil penelitian ini juga sejalan dengan penelitian yang dilakukan oleh Fauzia (2014) di Jakarta yang menyebutkan bahwa status ekonomi memiliki hubungan yang signifikan dengan pemilihan tempat persalinan $(p=0,001)$. Hasil ini juga sesuai 
dengan teori yang menyebutkan bahwa status ekonomi sebagai salah satu faktor enabling terhadap pemanfaatan pelayanan kesehatan. Status ekonomi yang diukur melalui pendapatan adalah seluruh penghasilan anggota keluarga di hitung dalam periode satu bulan. Besarnya pendapatan akan mempengaruhi pemanfaatan terhadap pelayanan kesehatan. Tinggi pendapatan mempengaruhi tinggi rendahnya upaya pelayanan kesehatan yang disediakan. Pendapatan mempunyai sifat yang elastis terhadap pelayanan kesehatan (Priyoto, 2019). Hasil ini dapat disebabkan oleh biaya yang harus disiapkan apabila memilih untuk merencanakan persalinan di FKTL. Walaupun seluruh peserta dijamin oleh JKN, pasien dan keluarga juga harus memikirkan akomodasi selama perjalanan dan perawatan di FKTL, terlebih bila lokasi FKTL tersebut jauh dari tempat tinggalnya. Sehingga status ekonomi tetap menjadi salah satu pertimbangan penting bagi pasien dan keluarga dalam merencanakan persalinannya.

\section{Hubungan Akses Pelayanan Kesehatan dengan Rencana} Pemilihan Tempat Persalinan

Hasil uji statistik diperoleh nilai $p=0,181 \quad(>0,05)$, maka diambil kesimpulan bahwa tidak ada hubungan antara pekerjaan dengan rencana pemilihan tempat persalinan. Hasil penelitian ini tidak sejalan dengan penelitian yang dilakukan oleh Amilda (2010) yang menunjukkan bahwa terdapat hubungan antara keterjangkauan sarana kesehatan dengan pemilihan tempat persalinan $(p=0,000)$. Hasil penelitian ini sejalan dengan penelitian yang dilakukan oleh Nasrullah, Mardjan dan Taufik (2016) di Pontianak yang menyebutkan bahwa tidak terdapat hubungan yang signifikan antara akses ke fasilitas kesehatan dengan preferensi penolong persalinan $(p=0,787)$. Hasil ini juga tidak sesuai dengan teori yang menyatakan bahwa akses ke fasilitas kesehatan adalah salah satu faktor enabling yang berpengaruh terhadap pemanfaatn pelayanan kesehatan. Akses pelayanan kesehatan merupakan salah satu variabel dari model organisasi dalam penggunaan pelayanan kesehatan. Dalam model ini, variabel yang dipakai adalah pencerminan perbedaan bentuk-bentuk sistem pelayanan kesehatan. Ketersediaan dan kemudahan menjangkau tempat pelayanan, akses terhadap sarana kesehatan dan transportasi merupakan salah satu pertimbangan keluarga dalam pengambilan keputusan mencari tempat

pelayanan kesehatan (Notoatmodjo, 2012b). Hal ini dapat disebabkan karena pada peserta JKN, peserta dapat memilih FKTP nya masingmasing sesuai dengan keinginannya, termasuk memilih FKTP yang terdekat dari tempat tinggalnya, atau FKTP yang fasilitas dan pelayanannya lebih baik. Dalam keadaan darurat pun, peserta JKN dapat mendatangi fasilitas kesehatan terdekat, sehingga jarak atau akses ke fasilitas kesehatan bukan menjadi pertimbangan utama bagi pasien untuk merencanakan persalinannya. $\mathrm{Hal}$ ini dapat dilihat bahwa sebagian besar responden memiliki akses dekat dengan fasilitas kesehatan dan memilih untuk merencanakan persalinannya di FKTP.

Hubungan Diagnosa Tenaga Medis dengan Rencana Pemilihan Tempat Persalinan

Hasil uji statistik diperoleh nilai $p=0,000 \quad(<0,05)$, maka diambil 
kesimpulan bahwa ada hubungan antara diagnosa tenaga medis dengan rencana pemilihan tempat persalinan. Dari hasil analisis diperoleh pula nilai $O R=132$, artinya responden yang memiliki diagnosa medis resiko tinggi mempunyai peluang 132 kali lebih besar untuk merencanakan persalinan di FKTL dibandingkan dengan responden yang memiliki diagnose tenaga medis resiko rendah. Hasil ini sejalan dengan hasil penelitian yang dilakukan oleh Indrian (2014) menunjukkan bahwa terdapat hubungan yang signifikan antara keseriusan penyakit dengan pemanfaatan pelayanan kesehatan $(p=0,000)$. Hasil ini juga sesuai dengan teori yang menyatakan bahwa faktor need pada seseorang mempengaruhi kebutuhan untuk memanfaatkan pelayanan kesehatan. Kebutuhan, yang digambarkan dengan keseriusan penyakit dalam diagnosa tenaga medis merupakan komponen yang langsung berhubungan dengan permintaan pelayanan kesehatan. Faktor predisposisi dan faktor pendukung dapat terwujud menjadi tindakan pencarian pengobatan, apabila tindakan itu dirasakan sebagai

kebutuhan. Kebutuhan merupakan dasar dan stimulus langsung untuk menggunakan pelayanan kesehatan. Kebutuhan pelayanan kesehatan dapat dikategorikan menjadi perceived need dan evaluated need (clinical diagnosis). Evaluated need atau diagnosa tenaga medis merupakan penilaian keadaan sakit yang didasarkan oleh penilaian tenaga medis (Priyoto, 2019). Hasil penelitian ini menunjukkan bahwa diagnosa tenaga medis menjadi pertimbangan paling penting bagi pasien dalam merencanakan tempat persalinannya. Mereka yang memiliki resiko persalinan tinggi lebih banyak merencanakan persalinannya di FKTL. Hal ini juga difasilitasi oleh JKN yang menerapkan sistem rujukan berjenjang. Rujukan dapat diberikan sesuai dengan indikasi medis yang diberikan oleh tenaga medis, sehingga pasien dapat merencanakan persalinannya dengan baik. Sedangkan dalam keadaan darurat, pasien dapat langsung mendatangi FKTL tanpa mengambil rujukan.

\section{KESIMPULAN}

Faktor yang paling dominan mempengaruhi rencana pemilihan tempat persalinan adalah diagnosis tenaga medis.

\section{SARAN}

Bagi Rumah Sakit Pertamina Bintang Amin Bandar Lampung agar dapat menjelaskan prosedur pelayanan kepada pasien apabila sewaktuwaktu mengalami keadaan gawat darurat saat persalinan, terutama pada pasien dengan diagnosis tenaga medis risiko tinggi. Penjelasan dapat dilakukan saat pasien selesai mendapatkan pelayanan ANC di poliklinik. Bagi peneliti lain agar dapat melanjutkan penelitian ini terkait dengan faktor-faktor yang mempengaruhi rencana pemilihan tempat persalinan, dengan menambahkan variabel lain yang memungkinkan dan mengontrol bias yang mungkin timbul.

\section{DAFTAR PUSTAKA}

Amilda, N. L. (2010) Faktor-Faktor Yang Berhubungan Dengan Pemilihan Pertolongan Persalinan Oleh Dukun Bayi. Semara.

Baba, K. et al. (2016) 'A Crosssectional Survey of Policies Guiding Second Stage Labor in Urban Japanese Hospitals, Clinics and Midwifery Birth Centers', BMC Pregnancy and Childbirth. BMC 
Pregnancy and Childbirth, 16(37), pp. 1-13. doi: 10.1186/s12884016-0814-2.

Babitsch, B., Gohl, D. dan Lengerke, T. von (2012) 'Re-revisiting Andersen's Behavioral Model of Health Services Use: A Systematic Review of Studies From', GMS Psycho-SocialMedicine, 9, pp. 1-15.

Badan Kependudukan dan Keluarga Berencana Nasional et al. (2017) Survei Demografi dan Kesehatan Indonesia 2017. Jakarta.

Badan Penyelenggara Jaminan Sosial Kesehatan (2013a) Panduan Praktis Pelayanan Kebidanan dan Neonatal. Jakarta.

Badan Penyelenggara Jaminan Sosial Kesehatan (2013b) Panduan Praktis Pelayanan Kesehatan. Jakarta.

Badan Pusat Statistik Indonesia (2015) Angka Kematian Ibu Menurut Pulau (Per 100.000 Kelahiran Hidup) Tahun 2015. Available at: https://www.bps.go.id/dynamicta ble/2018/06/05/1439/angkakematian-ibu-menurut-pulau-per100-000-kelahiran-hidup2015.html (Accessed: 13 February 2019).

Dahlan, M. S. (2016) Statistik Untuk Kedokteran dan Kesehatan. 6th edn. Jakarta: Salemba Empat.

Dermawan, R. (2018) Pengambilan Keputusan: Landasan Filosofis, Konsep, dan Aplikasi. 5th edn. Bandung: Alfabeta.

Fauzia, R. (2014) Faktor-Faktor Yang Berhubungan Dengan Keputusan Pemilihan Tempat Persalinan Pasien Poliklinik Kandungan dan Kebidanan di Rumah Sakit Ibu dan Anak Kemang Medical Care Tahun 2014. Jakarta.

Hartono, B. (2010) Manajemen Pemasaran Untuk Rumah Sakit. Jakarta: Rineka Cipta.
Hastono, S. P. (2017) Analisis Data Pada Bidang Kesehatan. 2nd edn. Depok: Rajagrafindo Persada.

Hermawan (2016) 'Strategi Pelayanan Kesehatan Yang "Pro Publik" Bagi Rumah Sakit', Jurnal Review Politik, 6(2), pp. 270-296. Indrian, P. T. (2014) Hubungan Persepsi Kerentanan Penyakit Dan Keseriusan Penyakit Dengan Pelayanan Kesehatan Pada Health Belief Model. Universitas Sebelas Maret.

Kementerian Kesehatan RI (2010) Pedoman Pelayanan Antenatal Terpadu. Jakarta.

Kementerian Kesehatan RI (2013) Riset Kesehatan Dasar (RISKESDAS) 2013, Laporan Nasional 2013. Jakarta.

Kementerian Kesehatan RI (2015) Rencana Strategis Kementerian Kesehatan Tahun 2015-2019. Jakarta.

Kementerian Kesehatan RI (2018) Hasil Utama Riskesdas 2018. Jakarta.

Menteri Kesehatan Republik Indonesia (2014) Peraturan Menteri Kesehatan Republik Indonesia Nomor 25 tahun 2014 tentang Upaya Kesehatan Anak. Indonesia.

Nasrullah, N., Mardjan danTaufik, M. (2016) Beberapa Faktor Yang Berhubungan dengan Preferensi Penolong Persalinan Pada Ibu Hamil di Wilayah Kerja Puskesmas Pimpinan Kecamatan Teluk Keramat Kabupaten Sambas. Pontianak.

Notoatmodjo, S. (2012a) Metodologi Penelitian Kesehatan. Jakarta: Rineka Cipta.

Notoatmodjo, S. (2012b) Promosi Kesehatan dan Perilaku Kesehatan. Revisi 2012. Jakarta: Rineka Cipta.

Priyoto (2019) Teori Sikap dan Perilaku dalam Kesehatan. 2nd 
edn. Yogyakarta: Nuha Medika.

Putri, M. D. (2016) 'Faktor-Faktor Yang Berhubungan Dengan Pemilihan Tempat Persalinan Tahun 2015 (Studi di Kecamatan Sarolangun Kabupaten Sarolangun Jambi)', Jurnal Kesehatan Masyarakat, 4(April), pp. 55-67.

Rakhmat, J. (2017) 'Sistem Komunikasi Intrapersonal', in Psikologi Komunikasi. 27th edn. Bandung: PT. Remaja Rosda Karya.

Republik Indonesia (2009) UndangUndang Nomor 44 Tahun 2009 tentang Rumah Sakit. Indonesia.

Robbins, S. P. dan Judge, T. A. (2017) Perilaku Organisasi. 5th edn. Jakarta: Salemba Empat.

Rumengan, D. S. S., Umboh, J. M. L. dan Kandou, G. D. (2015) 'Faktor-Faktor yang Berhubungan dengan Pemanfaatan Pelayanan Kesehatan Pada Peserta BPJS Kesehatan di Puskesmas Paniki Bawah Kecamatan Mapanget Kota Manado District of Manado', JIKMU, 5(1), pp. 88-100.

Rusdiyanti, I. (2017) 'Faktor-Faktor Yang Mempengaruhi Keputusan Ibu Dalam Memilih Tempat Persalinan di BPM', Healty-Mu, $1(2)$.

Sampeluna, N., Hamzah, A. and Acuan, K. (2013) Faktor Yang Berhubungan

Pemanfaatan

Kesehatan di RSUD Lakipadada Kabupaten Tana Toraja. Makassar.

Satrianegara, M. F. (2014) Organisasi dan Manajemen Pelayanan Kesehatan. Jakarta: Salemba Medika.

Sunarsih dan Ernawati (2017) 'Perbedaan Terapi Massage dan Terapi Relaksasi Dalam Mengurangi Nyeri Persalinan di Bidan Praktik Swasta (BPS)
Ernawati Kecamatan Banyumas', Jurnal Kesehatan Poltekkes Tanjung Karang, 8(1), pp. 8-12.

Tobing, S. I. B. L. (2018) 'FaktorFaktor Yang Berhubungan Dengan Perilaku Ibu Bersalin Dalam Pemanfaatan BPJS di Puskesmas Tenayan Raya', Jurnal Endurance, 3(1), pp. 25-32.

United Nations (2015) Sustainable Development Goals; Goal 3: Ensure healthy lives and promote well-being for all at all ages. Available at: https://www.un.org/sustainabled evelopment/health/ (Accessed: 13 February 2019).

World Health Organization (2019) Hospitals. Available at: https://www.who.int/hospitals/en /\%0D (Accessed: 26 March 2019).

Wulandari, C. et al. (2016) Faktor Yang Berhubungan Dengan Pemanfaatan Pelayanan Kesehatan di UPTD Puskesmas Langara Kecamatan Wawonii Barat Kabupaten Konawe Kepulauan Tahun 2016. Kendari. 